\title{
Engaging with Religious Difference
}

\section{William T. Hyndman III}

Florida A\&M University

Hubers, John. (2016). I am a Pilgrim, a Traveler, a Stranger: Exploring the Life and Mind of the First American Missionary to the Middle East, the Reverend Pliny Fisk (1792-1825). Eugene, OR: Pickwick Publications. 224 pp. ISBN 13 9781498282987.

This short book is an exploration of the life of the first American missionary to the Middle East, Rev. Pliny Fisk. Part biography and part analysis, the author Dr. John Hubers, uses Edward Said's 'orientalist' model as a prism through which to view the Rev. Fisk's mission. Born in New England in 1792, Pliny Fisk died in Beirut during his mission in 1825. This book makes use of his diaries and other archival material to examine his mission. The book will be of interest to education abroad professionals because it examines a very early intercultural experience of Americans in the Middle East.

The author, Dr. John Hubers, currently serves as Director of Global Education and Professor of Missiology at Northwestern College in Orange City, Iowa. For many years he worked as Supervisor of the Reformed Church in America's Mission Programs in the Middle East and South Asia. He lived in Oman and Bahrain for over ten years.

When Christian missionaries are written about, writers often tend towards one of two extremes, either to laud them as holy, saintly men and women, or to excoriate them as a manifestation of western imperialism. The author of this volume has avoided either of these extremes and instead seeks to show the Rev. Pliny Fisk as a complex man. Fisk grew up in New England and was educated at Andover seminary and Middlebury College and he held strong Calvinist beliefs.

At the time when Fisk arrived in the Middle East the Ottoman Empire stretched from North Africa to Europe and the frontier of Persia. While the majority of those living within the borders of the Empire were Muslim, there were also many Christians and Jews. From the outset Fisk and his colleague, Levi Parsons had certain preconceived notions about the religious and cultural others with whom they would interact. They understood that Muslims, Christians and Jews shared their belief in one God and in the basic facts of the Old Testament. For Fisk and Parsons these common beliefs were a "glimmer of light" in what they perceived to be "impenetrable darkness."

Fisk and Parsons might have befriended the Armenian Christians, Orthodox Christians, and the Catholics they encountered, who graciously received them, yet they remained apart from those who might have assisted them in their mission. With regards to Muslims, Fisk admitted that there was 
"much truth in their system." However, with Muslims as well Fisk and Parsons were never able to appreciate their hospitality and never sought to understand the religious other.

Hubers looks at the mission of Fisk using several themes. Among them are the objectification of the religious other, the problem of a text-based mission, viewing otherness as a threat rather than an opportunity, and viewing Ottoman otherness through a Biblical lens. Hubers argues that while Fisk in theory saw all men and women as his fellow human beings, ultimately he remained estranged from them. For Fisk, those who held different religious beliefs were adversaries with whom he must engage in a sparring match, not fellow believers with whom he should engage in dialogue.

The Ottoman Empire was an alien and alienating place to Pliny Fisk when he arrived. It remained that to him till the day he died. His tragedy in this sense was not the failure of his evangelical mission. It was his failure to find the "fellow" in his Ottoman "fellow being." In this case the most fitting epitaph on his life may be the one he wrote for himself. "I am a Pilgrim, a Traveler, a stranger. I have no home on earth. I see it in the skies” (p. 198).

Those who work in the field of education abroad have almost certainly encountered students, who like the Rev. Fisk, kept a distance from their host culture and rather than immersing themselves and seeking to understand and make friends, stood aloof. Such students miss an opportunity to learn from those different from themselves. In a similar way, Rev. Pliny Fisk missed opportunities for fellowship and dialogue with other people of faith and his mission was unsuccessful. 